\title{
Synthesis of Novel Arylazothiazolyl-thiophene Dyes for Solar Cell and Nonlinear Optical Materials
}

\author{
Mohamed E. Khalifa, ${ }^{1,2}, *$ Muhammed S. Al-Amoudi, ${ }^{1}$ Adil A. Gobouri, ${ }^{1}$ \\ Amar Merazga ${ }^{3}$ and Ahmed A. Fadda ${ }^{4}$ \\ ${ }^{1}$ Department of Chemistry, Faculty of Science, Taif University, Taif 21974, Saudi Arabia \\ ${ }^{2}$ Department of Chemical Engineering, Higher Institute of Engineering and Technology, New Damietta, Egypt \\ Tel. +966569846966 \\ ${ }^{3}$ Department of Physics, Faculty of Science, Taif University, Taif 21974, Saudi Arabia \\ ${ }^{4}$ Department of Chemistry, Faculty of Science, Mansoura University, Mansoura ET-35516, Egypt \\ *Corresponding author: E-mail: mohamedezzat200@ hotmail.com
}

Received: 28-09-2015

\begin{abstract}
Synthesis and investigation of new donor-acceptor conjugated $N$-(5-arylazothiazol-2-yl)-2-aminothiophene derivatives with the aim to elucidate the contribution of their interaction with solvent molecules upon intramolecular charge transfer for their potential solar cells application is reported. The UV-visible and emission spectra measurements indicated that the properties of the synthesized dyes had a significant effect on the visible absorption and emission maxima. The effect of the donor and acceptor groups were studied for the nonlinearity based on their HOMO-LUMO band gap energy. The dye-sensitized solar cells (DSSCs) were assembled by using the newly synthesized aryl thiazolyl-thiophene dyes as sensitizers. The promising results of $J_{\mathrm{SC}}\left(2.46 \times 10^{-2}\right.$ and $\left.4.07 \times 10^{-2} \mathrm{~mA} / \mathrm{cm}^{2}\right)$, the $V_{\mathrm{OC}}(0.429 \mathrm{~V}$ and $0.426 \mathrm{~V})$ and the FF $(0.66 \%)$ values obtained compared to other organic and natural sensitizer were due to the better interaction between the carboxyl and carbonyl groups of aryl azo molecule attached to the thiazolyl nucleus and the surface of $\mathrm{TiO}_{2}$ porous film.
\end{abstract}

Keywords: Aryl azo thiazol; HOMO-LUMO; nonlinear optical materials; Solar cells; donor- $\pi$-bridge-acceptor

\section{Introduction}

Organic dyes exhibit many advantages as an alternative to the noble metal complex sensitizers, as the molecular structures of organic dyes are in diverse form and can be easily designed and synthesized. The organic dyes are superior to noble metal complexes regarding the cost, environmental issues and the high molar extinction coefficients of organic dyes are making them attractive for thin film and solid-state dye sensitized solar cells (DSSCs). For example, they exhibit higher efficiencies compared with that of Ru complexes in p-type DSSCs. ${ }^{1}$ Generally, donor$\pi$-bridge-acceptor (D- $\pi$-a) structure is the common character of these organic dyes and with this construction, it is easy to design new dye structures, extend the absorption spectra, adjust the highest occupied molecular orbital (HOMO), the lowest unoccupied molecular orbital (LU-
MO) levels and complete the intramolecular charge separation. When a dye absorbs light, intramolecular charge transfer occurs from accepting subunit (A) to donating subunit (D) through the $\pi$-bridge. For n-type DSSCs, the excited dye injects the electron into the conduction band of the semiconductor via the electron acceptor group A. $^{2} \mathrm{Ho}-$ wever, in p-type DSSCs, the excited dye captures the electron from the valence band of the semiconductor to complete the interfacial charge transfer. Many efforts have been made to change the different parts of organic dyes to optimize DSSCs performance. To date, hundreds of n-type organic dyes including coumarin, indoline, tetrahydroquinoline, triarylamine, heteroanthracene, carbazole, $\mathrm{N}, \mathrm{N}$ dialkylaniline, hemicyanine and oligothiophene dyes have been adopted to act as sensitizers for DSSCs and have obtained impressive efficiencies. ${ }^{3}$ Sensitizers for p-type semiconductors aimed for use in tandem DSSCs have also been 
developed in recent years. ${ }^{4-7}$ Zhai and co-workers reported on oligothiophene dyes for DSSCs with an efficiency value of 3.4\%. ${ }^{8}$ Subsequently, Otsubo, Harima, and co-workers further developed the oligothiophene sensitizers through adjusting the number of thiophenes and introducing alkyl chains into the corresponding thiophene frameworks. ${ }^{9}$ However, the efficiency values of oligothiophene dyes were not improved due to dye aggregation caused by strong intermolecular $\pi$-conjugated interactions. ${ }^{9}$

In the past years, much attention has been paid to organic nonlinear optical materials (NLO) due to their promising application in optoelectronics technology, large nonlinear response, extremely fast switching time and convenient optimization routes through molecular engineering compared to the currently studied inorganic materials. ${ }^{10-13}$ Thiophene derivatives are versatile building blocks for the synthesis of donor-acceptor substituted $\pi$ conjugated systems for several optical applications. Recently, the synthesis of novel formyl $\pi$-conjugated systems (bithiophenes, ${ }^{14}$ oligothiophenes ${ }^{15}$ arylthiophenes ${ }^{16}$ and arylbithiophenes ${ }^{17}$ ) has been reported through several methods of synthesis such as cross-coupling reactions (Stille, ${ }^{15}$ Suzuki ${ }^{16,17}$ ), metalation followed by quenching with DMF, ${ }^{14}$ Vilsmeier-Haack formylation ${ }^{18}$ and Vilsmeier-Haack Arnold reactions. ${ }^{17}$ In the light of the previously mentioned literature, we decided to synthesize new $N$ (5-arylazothiazol-2-yl)-2-aminothiophene dyes to characterize their electrochemical properties and their viability in solar cells and nonlinear optical materials applications. In addition, the effect of increasing conjugation through the addition of thiophene unit and its influence on the optical and redox properties has been investigated.

\section{Experimental}

\section{1. Materials and Methods}

\section{1. 1. Chemicals and Reagents}

All the chemicals and solvents used in this study were obtained from Merck (Germany) and Sigma-Aldrich chemical company (Germany).

\section{1. 2. Instrumentation}

Melting points of the synthesized compounds were determined in open-glass capillaries on Stuart- SMP20 melting point apparatus (Bibby Scientific Limited, Staffordshire, UK) and are uncorrected. Elemental analyses (C, H, N) were conducted using the Perkin-Elmer 2400 Analyzer, series II (Perkin Elmer Co., Shelton, UK), the results were found to be in good agreement $( \pm 0.3 \%)$ with the calculated values. The infrared spectra were recorded on a Perkin Elmer Alpha platinum-ATR spectrometer, and the ${ }^{1} \mathrm{H}$ NMR, ${ }^{13} \mathrm{C}$ NMR spectra were measured on a Bruker WP 300 (Bruker, MA, USA) in dimethyl sulfoxide
(DMSO- $d_{6}$ ) using tetramethylsilane (TMS) as an internal standard. The ${ }^{1} \mathrm{H}$ NMR chemical shifts were reported as parts per million (ppm) downfield from tetramethylsilane (TMS). The splitting patterns are designated as follows; s, singlet; d, doublet; $\mathrm{m}$, multiplet. Mass spectra were recorded on GC-MS spectrometer (Shimadzu Qp-2010 Plus, Kyoto, Japan). UV-visible spectra were measured using Perkin Elmer spectrometer (Perkin Elmer Co., Shelton, UK). Cyclic voltammetry measurements were made using a conventional three electrode cell configuration linked to an $E G$ and $G$ model 283 Potentiostat. The platinum electrode surface was $7.85 \times 10^{-3} \mathrm{~cm}^{2}$ as a working electrode, coiled platinum wire as a counter electrode and saturated $\mathrm{Ag} / \mathrm{AgCl}$ as a reference electrode. The potential was calculated relative to the $\mathrm{Ag} / \mathrm{AgCl}$ reference electrode at $25^{\circ} \mathrm{C}$ and with $0.1 \mathrm{~mol} / \mathrm{L}$ tetraethyl ammonium chloride (TEACl) as background electrolyte. Cyclic voltammograms were recorded after background subtraction and IR compensation to minimize double-layer charging current and solution resistance. The working electrode was polished on a polisher Ecomet grinder. Cyclic voltammetric data were obtained at scan rate ranging from 0.02 to $5 \mathrm{~V} / \mathrm{s}$ in non- aqueous media at $(25 \pm 2){ }^{\circ} \mathrm{C}$. All working solutions were thoroughly degassed with oxygen free nitrogen, and a nitrogen atmosphere was maintained above the solution throughout experimental studies. All of the microanalyses and spectral analyses were performed at the Micro Analytical Centres of Taif (CHN, IR, UV-Visible spectra and cyclic voltammetry) and King Abdel-Aziz University ( ${ }^{1} \mathrm{H}$ NMR analysis), Saudi Arabia and Micro Analytical Center, Mansoura University (Mass spectra), Egypt.

\section{2. Computation}

All the ab initio DFT calculations were performed with the program package $\mathrm{DMol}^{3}$ in Materials Studio (Version 7.0) of Accelrys Inc., on personal computers. In the $\mathrm{DMol}^{3}$ method, ${ }^{19}$ the physical wave functions are expanded in terms of accurate numerical basis sets. We used a double-numeric quality basis set with polarization functions (DNP). The size of the DNP basis set is comparable to Gaussian $6-31 \mathrm{G},{ }^{* *}$ but the DNP is more accurate than the same size Gaussian basis set. ${ }^{20}$ AER, all electrons with scalar relativistic correction, ${ }^{21}$ was used as the treatment for core electrons. The generalized gradient-corrected (GGA) function by Perdew, Barke, and Ernzerhof (PBE) was employed. ${ }^{22} \mathrm{~A}$ Fermi smearing of 0.002 hartree (Ha) $(1 \mathrm{Ha}=27.2114 \mathrm{eV})$ and a global orbital cutoff of $5.5 \AA$ were used to improve computational performance.

\section{3. Fabrication of the Dye-sensitized Solar Cells (DSSCs)}

The $\mathrm{TiO}_{2}$ electrodes were prepared, rinsed with water and ethanol, sintered at $500{ }^{\circ} \mathrm{C}$ for $30 \mathrm{~min}$ and exposed 
to an $\mathrm{O}_{2}$ plasma with the guide of the reported techniques. ${ }^{23,24}$ Then they were immersed into a $0.5 \mathrm{mM}$ photosensitizer solution (ethanol) containing synthesized compounds $\mathbf{5 a}$ or $\mathbf{5 b}$, for $24 \mathrm{hrs}$ at room temperature. Pt-counter electrodes were prepared by placing a drop of an $\mathrm{H}_{2} \mathrm{PtCl}_{6}$ solution (2 mg Pt in $1 \mathrm{~mL}$ ethanol) on the fluorine doped tin oxide (FTO) glass and heating it (at $400{ }^{\circ} \mathrm{C}$ ) for $15 \mathrm{~min}$. The dye-adsorbed $\mathrm{TiO}_{2}$ electrodes and the $\mathrm{Pt}$ counter electrodes were assembled into a sealed sandwichtype cell by heating at $80{ }^{\circ} \mathrm{C}$, using a hot-melt ionomer film Surlyn (Solaronix) as a spacer between the electrodes. A drop of the electrolyte solution was placed in the drilled hole of the counter electrode and was driven into the cell via vacuum backfilling. Finally, the hole was sealed using additional Surlyn and a cover glass $(0.1 \mathrm{~mm}$ thickness). Both the photosensitizer-adsorbed $\mathrm{TiO}_{2}$ electrode and the Pt-counter electrode were sealed with $60 \mathrm{~mm}$ thick Surlyn (Solaronix).

\section{4. Synthesis}

\section{4. 1. Synthesis of 5-arylazo-2-aminothiazole Derivatives 3a and 3b:}

A hydrochloric acid solution ( $3 \mathrm{~mL}$ ) of ethyl 4-aminobenzoic acid $\mathbf{2 a}$ or 4 -aminoacetophenone $\mathbf{2 b}(0.01$ mol, 1.37 or $1.35 \mathrm{~g}$ respectively) and an aqueous solution $(5 \mathrm{~mL})$ of sodium nitrite $(0.01 \mathrm{~mol}, 0.69 \mathrm{~g})$ were mixed and stirred at $0{ }^{\circ} \mathrm{C}$ for 30 minutes. The prepared diazonium salt was added to ethanolic solution $(20 \mathrm{~mL})$ of the coupling component 2-aminothiazole $1(0.01 \mathrm{~mol}, 1 \mathrm{~g})$ containing sodium acetate $(3 \mathrm{~g})$ and continued stirring at $0{ }^{\circ} \mathrm{C}$ for $2 \mathrm{hrs}$. The resulting product was filtered and washed with water, dried, and recrystallized from ethanol.

\section{5-(4-Carboxyphenylazo)-2-aminothiazole (3a):}

Reddish brown solid, yield: $81 \%$; mp $183-185{ }^{\circ} \mathrm{C}$. IR $\left(\bar{v} / \mathrm{cm}^{-1}\right): 3368,3236\left(\mathrm{NH}_{2}\right), 2850-3000(\mathrm{OH}), 1685$ $(\mathrm{C}=\mathrm{O}) .{ }^{1} \mathrm{H}$ NMR $(\delta / \mathrm{ppm}): 6.85\left(\mathrm{~s}, 1 \mathrm{H}\right.$, thiazole $\left.\mathrm{C}_{4}-H\right)$, $7.45(\mathrm{~d}, 2 \mathrm{H}, \operatorname{Ar}-H, J=8.10 \mathrm{~Hz}), 7.90(\mathrm{~d}, 2 \mathrm{H}, \mathrm{Ar}-H, J=$ $1.75 \mathrm{~Hz}), 8.35\left(\mathrm{~s}, 2 \mathrm{H}, \mathrm{NH}_{2}\right), 10.65(\mathrm{~s}, 1 \mathrm{H}, \mathrm{COOH})$. MS $\left(\mathrm{M}^{+}+\mathrm{H}\right.$; CI iso-butane): $\mathrm{m} / \mathrm{z}=249(100.0 \%)$. Anal. Calcd. For $\mathrm{C}_{10} \mathrm{H}_{8} \mathrm{~N}_{4} \mathrm{O}_{2} \mathrm{~S}$ (Mol. Wt.: 248.26): C, 48.38; H, 3.25; N, 22.57 (Found: C, 48.17; H, 3.11; N, 20.42).

\section{5-(4-Acetylphenylazo)-2-aminothiazole (3b):}

Brown solid, yield: $73 \%$; mp $243{ }^{\circ} \mathrm{C}$. IR $\left(\overline{\mathrm{v}} / \mathrm{cm}^{-1}\right)$ : 3358, $3244\left(\mathrm{NH}_{2}\right), 1668(\mathrm{C}=\mathrm{O}) .{ }^{1} \mathrm{H}$ NMR $(\delta / \mathrm{ppm}): 2.45$ $\left(\mathrm{s}, 3 \mathrm{H}, \mathrm{COCH}_{3}\right), 6.90\left(\mathrm{~s}, 1 \mathrm{H}\right.$, thiazole $\left.\mathrm{C}_{4}-H\right), 7.50(\mathrm{~d}, 2 \mathrm{H}$, $\operatorname{Ar}-H, J=7.95 \mathrm{~Hz}), 7.85(\mathrm{~d}, 2 \mathrm{H}, \mathrm{Ar}-H, J=1.80 \mathrm{~Hz}), 8.15$ $\left(\mathrm{s}, 2 \mathrm{H}, \mathrm{NH}_{2}\right) . \mathrm{MS}\left(\mathrm{M}^{+} ; \mathrm{EI}\right): \mathrm{m} / \mathrm{z}=246(34.7 \%), 238$ (7.1\%), 203 (7.8\%), 152 (7.1\%), $147(12.9 \%), 135$ (18.5\%), 129 (31.4\%), 120 (33.3\%), $100(25.5 \%), 71$ (23.2\%), 57 (36.5\%), 44 (100.0\%). Anal. Calcd. For $\mathrm{C}_{11} \mathrm{H}_{10} \mathrm{~N}_{4} \mathrm{OS}$ (Mol. Wt.: 246.29): C, 53.64; H, 4.09; N, 22.75 (Found: C, 53.49; H, 4.17; N, 22.81).

\section{4. 2. Synthesis of 2-(N-acetylamino)-5-(arylazo)- thiazole Derivatives $4 \mathrm{a}$ and $4 \mathrm{~b}$ :}

A mixture of 5-arylazo-2-aminothiazole $\mathbf{3 a}$ or $\mathbf{3 b}$ $(0.005 \mathrm{~mol})$ and acetic anhydride $(5 \mathrm{~mL})$ was heated on a water bath at $100{ }^{\circ} \mathrm{C}$ for $2 \mathrm{hrs}$. The reaction mixture allowed to cool at room temperature and then recrystallized from ethanol to obtain the corresponding 2-( $\mathrm{N}$-acetylamino)-5-(arylazo)-thiazole derivatives $\mathbf{4 a}$ or $\mathbf{4 b}$.

\section{2-(N-Acetylamino)-5-(4-carboxyphenylazo)-thiazole} (4a):

Reddish brown solid, yield: $66 \%$; $\mathrm{mp} 212-213{ }^{\circ} \mathrm{C}$. IR ( $\left(\bar{v} / \mathrm{cm}^{-1}\right)$ : $3186(\mathrm{NH}), 2850-3000(\mathrm{OH}), 1681$ (broad, $\mathrm{C}=\mathrm{O}) .{ }^{1} \mathrm{H}$ NMR $(\delta / \mathrm{ppm}): 2.25$ (s. $\left.3 \mathrm{H}, \mathrm{CH}_{3}\right), 7.00(\mathrm{~s}, 1 \mathrm{H}$, thiazole $\left.\mathrm{C}_{4}-H\right), 7.40(\mathrm{~d}, 2 \mathrm{H}, \mathrm{Ar}-H, J=8.10 \mathrm{~Hz}), 7.80(\mathrm{~d}$, $2 \mathrm{H}, \operatorname{Ar}-H, J=1.85 \mathrm{~Hz}$ ), 10.45 (s, $1 \mathrm{H}, \mathrm{COOH}), 11.45$ (s, $1 \mathrm{H}, \mathrm{N} H)$. MS $\left(\mathrm{M}^{+}+\mathrm{H}\right.$; CI iso-butane $): \mathrm{m} / \mathrm{z}=291$ (100.0\%). Anal. Calcd. For $\mathrm{C}_{12} \mathrm{H}_{10} \mathrm{~N}_{4} \mathrm{O}_{3} \mathrm{~S}$ (Mol. Wt.: 290.3): C, 49.65; H, 3.47; N, 19.30 (Found: C, 49.47; H, $3.31 ; \mathrm{N}, 19.22)$.

2-(N-Acetylamino)-5-(4-acetylphenylazo)-thiazole (4b): Brown solid, yield: $52 \%$; $\mathrm{mp} 282-283{ }^{\circ} \mathrm{C}$. IR $\left(\bar{v} / \mathrm{cm}^{-1}\right): 3164(\mathrm{NH}), 1682(\mathrm{C}=\mathrm{O}), 1665(\mathrm{C}=\mathrm{O}) .{ }^{1} \mathrm{H}$

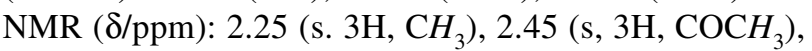
$6.90\left(\mathrm{~s}, 1 \mathrm{H}\right.$, thiazole $\left.\mathrm{C}_{4}-H\right), 7.45(\mathrm{~d}, 2 \mathrm{H}, \mathrm{Ar}-H, J=8.10$ $\mathrm{Hz}), 7.85$ (d, $2 \mathrm{H}, \mathrm{Ar}-H, J=1.85 \mathrm{~Hz}), 11.15(\mathrm{~s}, 1 \mathrm{H}, \mathrm{NH})$. MS $\left(\mathrm{M}^{+} ; \mathrm{EI}\right): \mathrm{m} / \mathrm{z}=288(22.6 \%), 245(12.2 \%), 223$ (15.7\%), 120 (44.8\%), 100 (25.5\%), 77 (11.6\%), 44 (100.0\%). Anal. Calcd. For $\mathrm{C}_{13} \mathrm{H}_{12} \mathrm{~N}_{4} \mathrm{O}_{2} \mathrm{~S}$ (Mol. Wt.: 288.32): C, 54.15; H, 4.20; N, 19.43 (Found: C, 54.02; $\mathrm{H}, 4.28 ; \mathrm{N}, 19.40)$.

\section{4. 3. Synthesis of 2-Amino-4-(arylazothiazol- 2-yl)amino-thiophene Derivatives 5 a and 5b:}

Three component reaction mixture, 2-( $N$-acetylamino)-5-(arylazo)-thiazole derivative $4 \mathbf{a}$ or $\mathbf{4 b}(0.005 \mathrm{~mol})$, sulphur element $(0.005 \mathrm{~mol}, 0.16 \mathrm{~g})$ and acetonitrile $(0.005 \mathrm{~mol}, 0.22 \mathrm{~g})$ underwent Gewald reaction by refluxing for $3 \mathrm{hrs}$ in dimethyl formamide (DMF) as a solvent and four drops of morpholine as a base catalyst. The solid products were collected, filtered, dried and recrystalized from ethanol to obtain the corresponding aryl azo thiazolyl-thiophene derivatives $\mathbf{5 a}$ or $\mathbf{5 b}$.

\section{2-Amino-4-(5-p-carboxyphenylazothiazol-2-yl)amino- thiophene (5a):}

Reddish brown solid, yield: $44 \%$; mp $243-244{ }^{\circ} \mathrm{C}$; IR ( $\left.\bar{v} / \mathrm{cm}^{-1}\right): 3326,3258,3184\left(\mathrm{NH}_{2}\right.$ and $\left.\mathrm{NH}\right), 2850-3000$ $(\mathrm{OH}), 1680(\mathrm{C}=\mathrm{O}) .{ }^{1} \mathrm{H}$ NMR $(\delta / \mathrm{ppm}): 5.35(\mathrm{~s}, 1 \mathrm{H}$, thiohpene $\left.\mathrm{C}_{5}-\mathrm{H}\right), 5.65\left(\mathrm{~s}, 1 \mathrm{H}\right.$, thiohpene $\left.\mathrm{C}_{3}-H\right), 7.10(\mathrm{~s}, 1 \mathrm{H}$, thiazole $\left.\mathrm{C}_{4}-H\right), 7.50(\mathrm{~d}, 2 \mathrm{H}, \mathrm{Ar}-H, J=7.90 \mathrm{~Hz}), 7.85(\mathrm{~d}$, $2 \mathrm{H}, \mathrm{Ar}-H, J=1.85 \mathrm{~Hz}), 8.25\left(\mathrm{~s}, 2 \mathrm{H}, \mathrm{NH}_{2}\right), 10.85(\mathrm{~s}, 1 \mathrm{H}$, $\mathrm{COOH}), 11.15$ (s, $1 \mathrm{H}, \mathrm{N} H) .{ }^{13} \mathrm{C} \mathrm{NMR}(\delta / \mathrm{ppm}): 168.67$, 
$160.17,149.23,141.33,139.76,134.46,131.22,130.27$ (2C), 128.84 (2C), 126.34, 121.32, 106.41. MS $\left(\mathrm{M}^{+}+\mathrm{H}\right.$; CI iso-butane): $\mathrm{m} / \mathrm{z}=346(100.0 \%)$. Anal. Calcd. For $\mathrm{C}_{14} \mathrm{H}_{11} \mathrm{~N}_{5} \mathrm{O}_{2} \mathrm{~S}_{2}$ (Mol. Wt.: 345.4): C, 48.68; H, 3.21; N, 20.28 (Found: C, 48.47; H, 3.08; N, 20.16).

\section{2-Amino-4-(5-p-acetylphenylazothiazol-2-yl)amino- thiophene (5b):}

Yellowish brown solid, yield: 52\%; mp 213-214 ${ }^{\circ} \mathrm{C}$; IR $\left(\bar{v} / \mathrm{cm}^{-1}\right): 3354,3271,3149\left(\mathrm{NH}_{2}\right.$ and $\left.\mathrm{NH}\right), 1663$ $(\mathrm{C}=\mathrm{O}) .{ }^{1} \mathrm{H}$ NMR $(\delta / \mathrm{ppm}): 2.50\left(\mathrm{~s}, 3 \mathrm{H}, \mathrm{COCH}_{3}\right), 5.30$ (s, $1 \mathrm{H}$, thiohpene $\left.\mathrm{C}_{5}-H\right), 5.55\left(\mathrm{~s}, 1 \mathrm{H}\right.$, thiohpene $\left.\mathrm{C}_{3}-H\right), 7.00$ $\left(\mathrm{s}, 1 \mathrm{H}\right.$, thiazole $\left.\mathrm{C}_{4}-H\right), 7.45(\mathrm{~d}, 2 \mathrm{H}, \mathrm{Ar}-H, J=7.90 \mathrm{~Hz})$, $7.80(\mathrm{~d}, 2 \mathrm{H}, \mathrm{Ar}-H, J=1.85 \mathrm{~Hz}), 8.15\left(\mathrm{~s}, 2 \mathrm{H}, \mathrm{N} H_{2}\right), 11.35$ (s, $1 \mathrm{H}, \mathrm{N} H) .{ }^{13} \mathrm{C}$ NMR $(\delta / \mathrm{ppm}): 186.48,158.94,148.62$, $140.08,138.38,135.93,133.66,129.64$ (2C), 128.05 (2C), 125.74, 119.54, 105.16, 25.81. MS ( $\mathrm{M}^{+}+\mathrm{H}$; CI isobutane): $\mathrm{m} / \mathrm{z}=344(100.0 \%)$. Anal. Calcd. For $\mathrm{C}_{15} \mathrm{H}_{13} \mathrm{~N}_{5} \mathrm{OS}_{2}$ (Mol. Wt.: 343.43): C, 52.46; H, 3.82; N, 20.39 (Found: C, 52.28; H, 3.88; N, 20.27).

\section{Results and Discussion}

\section{1. Chemistry}

To accomplish and attend our plan of the synthesis of 2-amino-4-(5-arylazothiazol-2-yl)aminothiophene derivatives $\mathbf{5 a}$ and $\mathbf{5 b}$ for solar cell and nonlinear optical materials applications, we have performed a two-step synthesis. Firstly, coupling of 2-aminothiazole 1 with aromatic diazonium salts of 4-aminobenzoic acid $\mathbf{2 a}$ and 4-aminoacetophenone $\mathbf{2} \mathbf{b}$ in presence of sodium acetate and ethanol afforded the corresponding 2-amino-5-arylazo-thiazole derivatives 3a and 3b. Free solvent acetylation of the 5-arylazo-2-aminothizole derivatives $\mathbf{3 a}$ and $\mathbf{3 b}$ using acetic anhydride under mild conditions yielded the corresponding 2-( $\mathrm{N}$-acetylamino)-5-(arylazo)-thiazole derivatives $\mathbf{4 a}$ and $\mathbf{4 b}$ respectively as shown in Scheme 1.

Secondly, the three component reaction mixture of 2-( $N$-acetylamino)-5-(arylazo)-thiazolederivatives $\mathbf{4 a}$ and/ or $\mathbf{4 b}$, sulphur element and acetonitrile underwent

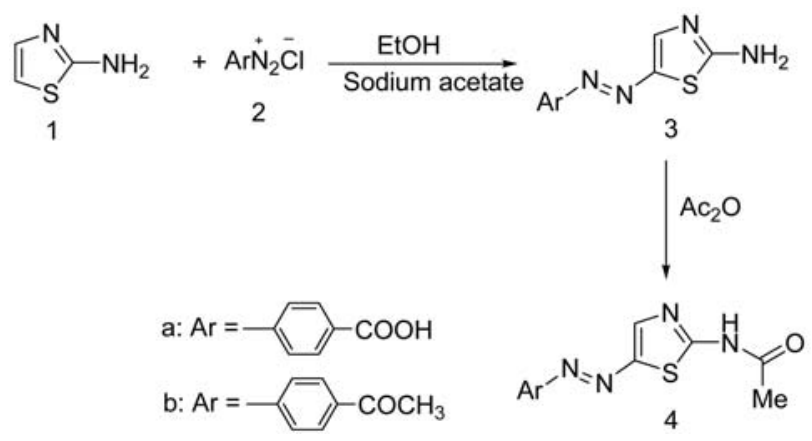

Scheme 1

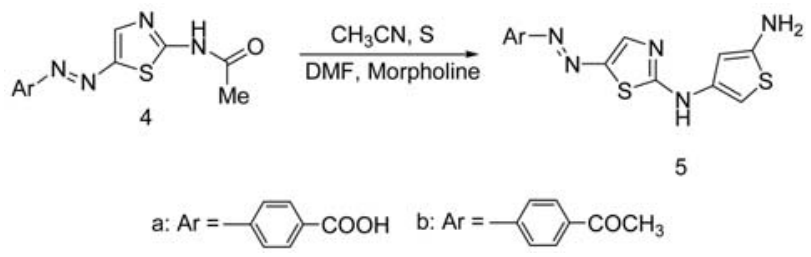

Scheme 2

Gewald synthesis in DMF and morpholine as a base catalyst, yielded the target products 2-amino-4-(arylazothiazol-2-yl)amino-thiophene $\mathbf{5 a}$ and $\mathbf{5 b}$ respectively as shown in Scheme 2.

The chemical structures of 2-amino-4-(arylazothiazol-2-yl)amino-thiophene derivatives $\mathbf{5 a}$ and $\mathbf{5 b}$ were established on the basis of their elemental analysis and spectral data. The IR spectrum of compound $\mathbf{5 b}$ as an example showed characteristic absorption bands at 3354, $3271 \mathrm{~cm}^{-1}$ for the $\mathrm{NH}_{2}$ group, strong absorption band at $3149 \mathrm{~cm}^{-1}$ for the $\mathrm{NH}$ stretching and band at $1663 \mathrm{~cm}^{-1}$ corresponding to the carbonyl group $(\mathrm{C}=\mathrm{O})$. The ${ }^{1} \mathrm{H}$ NMR spectrum of $\mathbf{5 b}$ exhibited singlet signal at $\delta=2.50$ ppm for three protons $\left(\mathrm{COCH}_{3}\right)$, three singlet signals at $\delta=5.30,5.55,7.00 \mathrm{ppm}$ corresponding to the thiophene $\mathrm{C}_{5}-\mathrm{H}$, thiophene $\mathrm{C}_{3}-\mathrm{H}$ and thiazole $\mathrm{C}_{4}-\mathrm{H}$ protons, respectively. The two doublet signals at $\delta=7.45$ and 7.80 ppm was attributed to the aromatic protons while the highly deshielded $\mathrm{NH}_{2}$ and $\mathrm{NH}$ protons appeared at $\delta=$ 8.15 and $11.35 \mathrm{ppm}$. The mass spectrum of the same compound showed molecular ion peak at $\mathrm{m} / \mathrm{z}=344\left(\mathrm{M}^{+}\right.$ $+\mathrm{H}, 100)$ which in agreement with molecular formula $\mathrm{C}_{15} \mathrm{H}_{13} \mathrm{~N}_{5} \mathrm{OS}_{2}+1$.

\section{2. Energy States of Nonlinear Optical Compounds}

\section{2. 1. Absorption Spectra Analysis}

Figures 1a,b show the UV-Visible absorption spectra of the two synthesized monoazo dyes $\mathbf{5} \mathbf{a}$ and $\mathbf{5 b}$ in chloroform and DMSO solutions, respectively. The spectra were studied at the range 300 to $650 \mathrm{~nm}$ at room temperature and were influenced by the structure of the electron donor-acceptor system, where the maximum absorbance wavelength $\left(\lambda_{\max }\right)$ and the cut-off edge wavelength $\left(\lambda_{\text {cut-off }}\right)$ were affected by the conjugation length and donor strength. Compound 5b has a stronger acceptor keto group than the carboxylate chromophore of $\mathbf{5 a}$ and thus it absorbs at higher wavelength. Therefore, these synthesized azo dyes could be used for solar cells since the absorption spectrum of the donor- $\pi$-acceptor could be extended towards longer wavelength by effective intramolecular charge transfer between donor and acceptor moieties. Meanwhile, the energy levels could be tuned by incorporating different electron donating and/or accepting groups and even the $\pi$ bridge. 


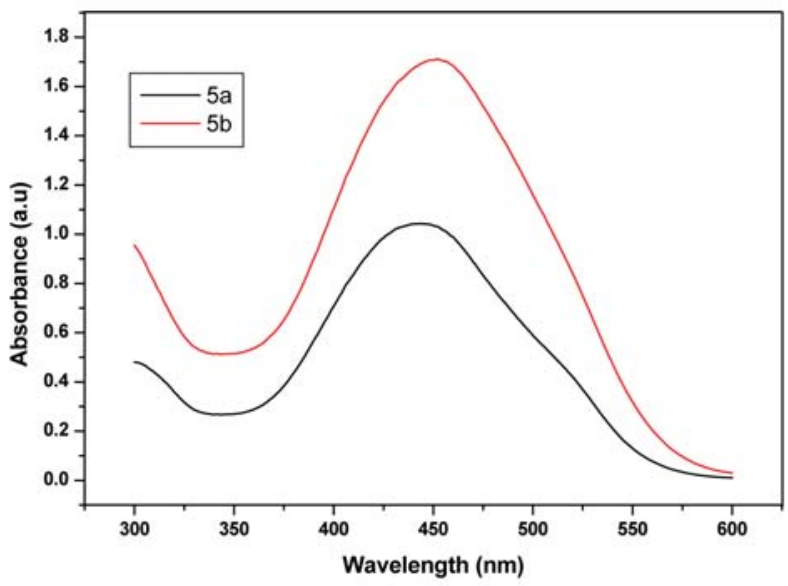

Figure 1a. UV-Visible absorption spectra of compound 5a $\left(\lambda_{\max }\right.$ $448 \mathrm{~nm})$ and $\mathbf{5 b}\left(\lambda_{\max } 446 \mathrm{~nm}\right)$ in $\mathrm{CHCl}_{3}$ solution

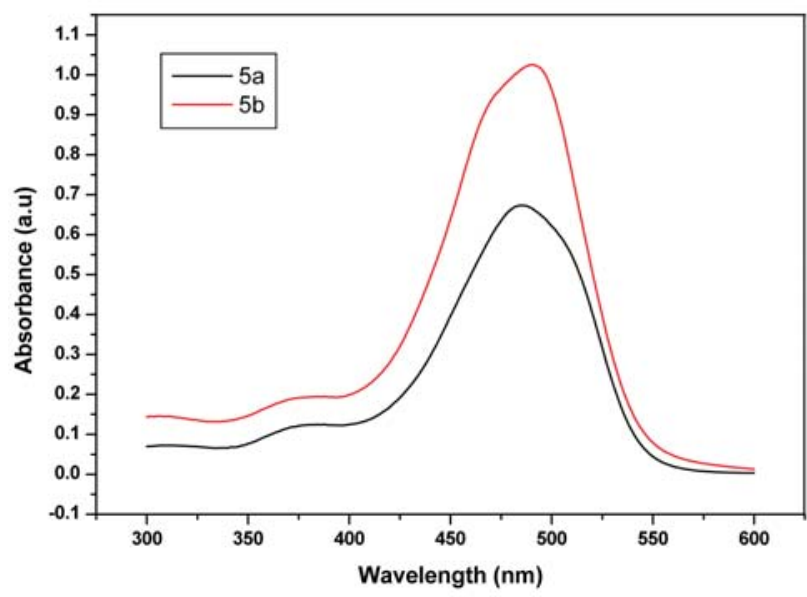

Figure 1b. UV-Vis absorption spectra of compound 5a $\left(\lambda_{\max } 487\right.$ $\mathrm{nm})$ and $\mathbf{5 b}\left(\lambda_{\max } 494 \mathrm{~nm}\right)$ in DMSO solution

\section{2. 2. Electrochemical Analysis of the Nonlinear Optical Compounds}

Electrochemical analysis was performed to determine the redox potentials using cyclic voltammetry technique to estimate the energy levels of the organic nonlinear optical compounds. The oxidation process corresponds to the removal of electron from the highest occupied molecular orbital (HOMO), whereas the reduction process corresponds to the lowest unoccupied molecular orbital (LUMO) being filled by electrons, and were determined by cyclic voltammetric measurements. ${ }^{25}$ The HOMO energy levels were calculated from the onset oxidation potential of cyclic voltammograms. The oxidation and reduction potentials are closely related to the energies of the HOMO and LUMO levels of the two organic NLO compounds $\mathbf{5 a}$ and $\mathbf{5 b}$ indicating important information regarding the magnitude of the energy gap of the two compounds. Figures $2 \mathrm{a}, \mathrm{b}$ show the cyclic voltammograms interpretation for compounds $\mathbf{5 a}$ and $\mathbf{5 b}$ in acetonitrile respectively, where, they appear to have a single reversible oxidative wave in a positive energy and another an irreversible reductive peak in a negative energy.

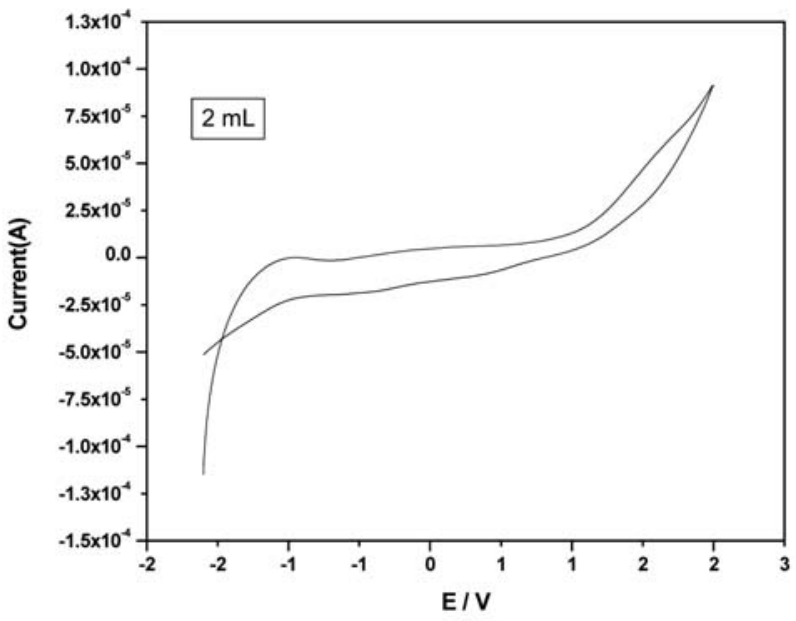

Figure 2a. Cyclic voltammograms interpretation of $\mathbf{5 a}$ in acetonitrile

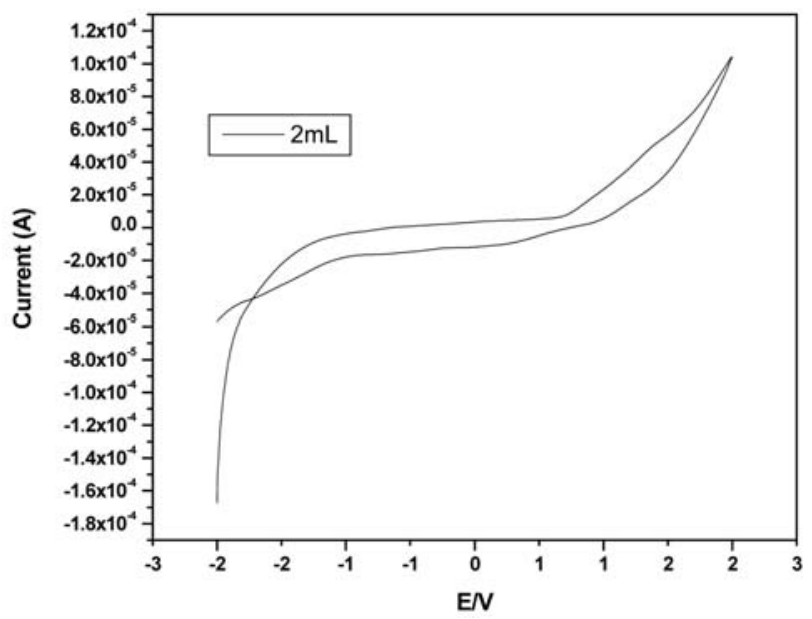

Figure 2b. Cyclic voltammograms interpretation of $\mathbf{5 b}$ in acetonitrile

Table 1. Electrochemical and spectroscopic analysis data of the synthesized dyes $\mathbf{5 a}$ and $\mathbf{5 b}$

\begin{tabular}{|c|c|c|c|c|c|}
\hline \multirow{2}{*}{ Dye } & \multicolumn{3}{|c|}{ Cyclic voltammetry } & \multicolumn{2}{|c|}{ Absorption spectroscopic data } \\
\hline & $E^{1 / 2}{ }_{o x}$ & $\mathbf{E}_{\text {номо }}(\mathrm{eV})$ & $E_{\text {LUMO }}(\mathrm{eV})$ & $\Delta \mathrm{E}_{\text {soect. }}(\mathrm{eV})$ & $\lambda_{\text {cut off }}(\mathrm{nm})$ \\
\hline $5 \mathrm{a}$ & 1.245 & -6.045 & -3.937 & 2.108 & 556 \\
\hline $5 \mathrm{~b}$ & 1.125 & -5.925 & -3.690 & 2.235 & 588 \\
\hline
\end{tabular}


The energy difference between HOMO and LUMO energy levels, normally called the HOMO-LUMO gap, could be estimated from the oxidation reduction potentials measurements. Estimation was performed in term of the optical energy gap of the absorption edge of the electronic spectrum. Thus, the HOMO-LUMO energy band gap in each compound was determined after combining the cyclic voltammetry and the electronic spectrum data. The results including the spectroscopic measurements data were collected in Table 1, exhibiting the small cathodic shift in the oxidation and reduction peaks of the chromophore $\mathbf{5 b}$ due to presence of its stronger acceptor.

\section{2. 3. Microscopic Nonlinearities of the Synthesized mono azo Derivatives 5a and 5b:}

Obviously, to have strong second-order NLO properties, the compound must possess a large first-order mo- lecular hyperpolarizability $(\beta) .{ }^{26}$ Therefore, the dipole moment $(\mu)$ and molecular hyperpolarizabilites $(\beta)$ of the two compounds $\mathbf{5 a}$ and $\mathbf{5 b}$ were calculated and tabulated in Table 2, showing that compound $\mathbf{5 b}$ has a higher firstorder molecular hyperpolarizability $(\beta)$ and a higher microscopic nonlinearity $(\mu \beta(0))$ that is explained by the lowest transition state.

\section{3. Molecular Orbital Calculations}

To gain insight on the electronic structure and optical properties of the organic synthesized dyes $\mathbf{5 a}$ and $\mathbf{5 b}$, the electronic distributions between the HOMO and LU$\mathrm{MO}$ calculated with $\mathrm{DMol}^{3}$ are illustrated in Figure 3. It indicates a pronounced intermolecular charge separation. The HOMO is delocalized over the $\pi$ system with the highest electron density centered at the central nitrogen atoms and the LUMO is located in anchoring groups through the $\pi$ bridge. The LUMO orientation over the ac-

Table 2. Measured absorption spectral data and calculated microscopic nonlinear optical parameters of the synthesized dyes $\mathbf{5} \mathbf{a}$ and $\mathbf{5 b}$

\begin{tabular}{|c|c|c|c|c|}
\hline Dye & $\mathrm{CHCl}_{3}$ & $\begin{array}{l}(\mathrm{nm}), \varepsilon\left(\mathrm{M}^{-1} \mathrm{c}\right. \\
\mu\left(\times 10^{-18} \mathrm{esu}\right)\end{array}$ & $\beta(0)\left(\times 10^{-30} \mathrm{esu}\right)$ & $\begin{array}{l}\text { Theoretical data } \\
\mu \beta(0)\left(\times 10^{-48} \mathrm{esu}\right)\end{array}$ \\
\hline$\overline{\mathbf{5 a}}$ & $476\left(6.7 \times 10^{4}\right)$ & 9.964 & 2.21 & 22 \\
\hline $5 \mathbf{b}$ & $467\left(6.7 \times 10^{4}\right)$ & 14.45 & 61.65 & 890 \\
\hline
\end{tabular}

$5 \mathbf{a}$

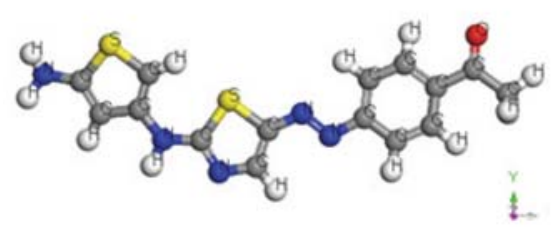

HOMO

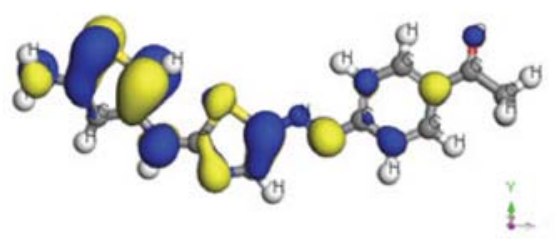

LUMO

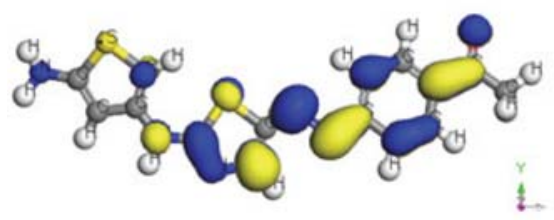

$\mathbf{5 b}$

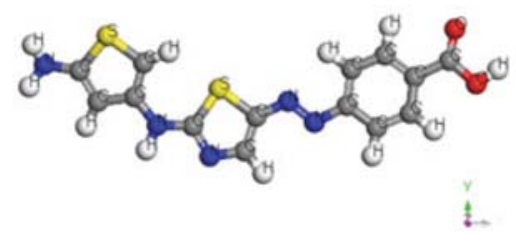

HOMO

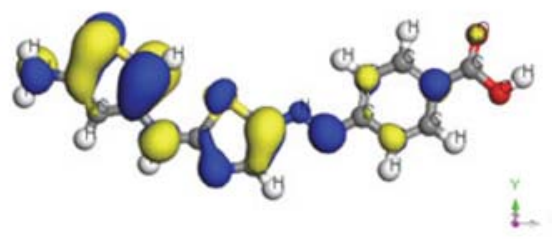

LUMO

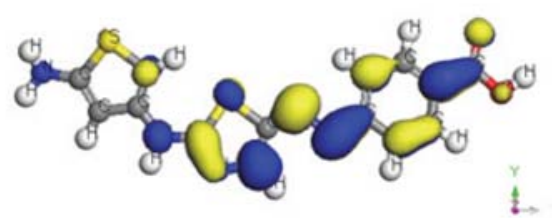

Figure 3. Molecular orbital's of the HOMO and LUMO of synthesized organic dyes $\mathbf{5 a}$ and $\mathbf{5 b}$ calculated with DMol ${ }^{3}$. 
ceptor group will be favorable towards the electron injection, assuming similar molecular orbital distribution when the dyes are attached to $\mathrm{TiO}_{2}$.

\section{4. Photovoltaic Performance of the DSSCs Fabricated from Dyes $5 a$ and $5 b$.}

The photovoltaic performance of the DSSCs 5a and $\mathbf{5 b}$ was measured and summarized in Table 3 and Figure 4, where the replacement of the carboxylic group in dye $\mathbf{5} \mathbf{a}$ by a keto group in dye $\mathbf{5 b}$ resulted in broadening the visible absorption spectrum which may be responsible for better photovoltaic performance; $\mathrm{J}_{\mathrm{sc}}$ of $\mathbf{5 b}$ is approximately doubled value compared to $\mathbf{5 a} \cdot{ }^{27}$ On the other hand, the increase of the overall conversion efficiency of the DSSC ( $\eta) \mathbf{5 b}$ to double value that of $\mathbf{5} \mathbf{a}$ can be ascribed to the better donating ability of this dye compared to dye 5a. The promising results; $J_{\mathrm{SC}}$ values $\left(2.46 \times 10^{-2}\right.$ and $\left.4.07 \times 10^{-2} \mathrm{~mA} / \mathrm{cm}^{2}\right)$, the $V_{\mathrm{OC}}$ values $(0.429 \mathrm{~V}$ and $0.426 \mathrm{~V})$ and the fill factor value $(\mathrm{FF}=0.66 \%)$ compared with other organic and natural sensitizer were due to the better interaction between the carboxyl and carbonyl groups of aryl azo molecule attached to the thiazolyl nucleus and the surface of $\mathrm{TiO}_{2}$ porous film. ${ }^{28,29}$

Table 3.The photovoltaic parameters of the synthesized dyes 5a and $\mathbf{5 b}$

\begin{tabular}{lcccc}
\hline Dye & $\begin{array}{c}\mathbf{J}_{\mathbf{S C}} \\
\left(\mathbf{m A} \mathbf{A} / \mathbf{c m}^{2}\right)\end{array}$ & $\begin{array}{c}\mathbf{V}_{\text {OC }} \\
(\mathbf{V})\end{array}$ & $\begin{array}{c}\mathbf{F F} \\
(\boldsymbol{\%})\end{array}$ & $\begin{array}{c}\boldsymbol{\eta} \\
(\boldsymbol{\%})\end{array}$ \\
\hline $\mathbf{5 a}$ & $2.46 \times 10^{-2}$ & 0.429 & 0.66 & $2.46 \times 10^{-2}$ \\
$\mathbf{5 b}$ & $4.07 \times 10^{-2}$ & 0.426 & 0.66 & $4.18 \times 10^{-2}$ \\
\hline
\end{tabular}

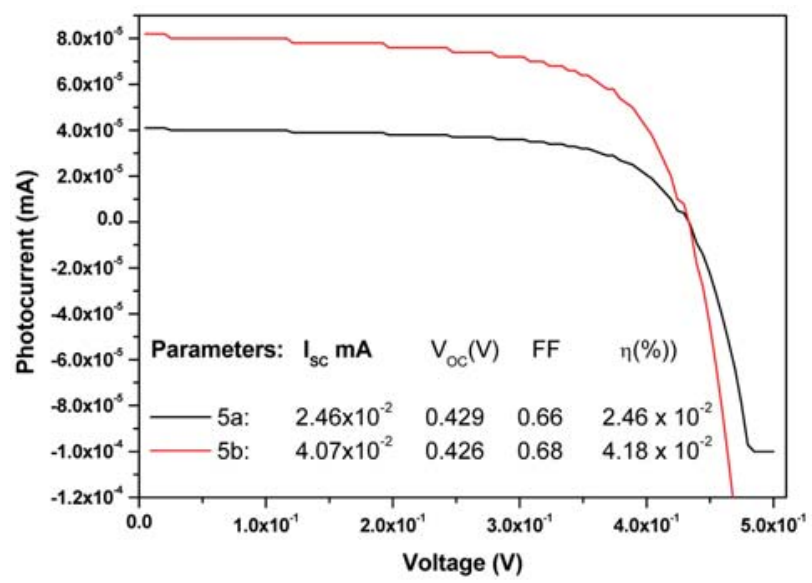

Figure 4. J-V characteristics of the DSSCs fabricated from dyes $\mathbf{5 a}$ and $\mathbf{5 b}$.

\section{Conclusion}

The $N$-(5-arylazothiazol-2-yl)-2-aminothiophene dyes $\mathbf{5 a}$ and $\mathbf{5 b}$ were successfully synthesized using the versatile Gewald synthesis from the active derivatives of 2amino-5-aryl mono azo thiazole and then investigated for their potential for solar cell and non-linear optics applications. The spectroscopy and electrochemical analysis have confirmed that the keto acceptor of dye $\mathbf{5 b}$ was a relatively stronger acceptor and enhanced the microscopic nonlinearity compared to the carboxylate one in dye 5a. This finding was supported by the data measured and calculated of HOMO-LUMO band gap energy. On the other hand, the bathochromic shift in DMSO indicated a good charge transfer between donor and acceptor, which enabled these newly synthesized mono azo thiazolyl-thiophene dyes to be applied in solar cells. Further improvement in the properties of the obtained compounds could be achieved later on, by increasing the conjugation, introducing stronger accepting and donating functional groups and increasing the planarity of the system using Triple Bond Bridge.

\section{References}

1. M. Ye, X. Wen, M. Wang, J. Iocozzia, N. Zhang, C. Lin, Z. Lin, Materials today 2105, 18, 155-162.

2. M. Wielopolski, J.-H. Kim, Y.-S. Jung, Y.-J. Yu, K.-Y. Kay, T. W. Holcombe, S. M. Zakeeruddin, M. Grätzel, J.-E. Moser, J. Phys. Chem. C 2013, 117, 13805-13815. http://pubs.acs.org/doi/abs/10.1021/jp402411h

3. A. Hagfeldt, G. Boschloo, L. Sun, L. Kloo, H. Pettersson, Chem. Rev. 2010, 110, 6595-6663. http://pubs.acs.org/doi/abs/10.1021/cr900356p

4. M. Borgstrom, E. Blart, G. Boschloo, E. Mukhtar, A. Hagfeldt, L. Hammarstrom, F. Odobel, J. Phys. Chem. B. 2005, 109, 22928-22934.

http://pubs.acs.org/doi/abs/10.1021/jp054034a

5. A. Morandeira, G. Boschloo, A. Hagfeldt, L. Hammarstrom, J. Phys. Chem. C. 2008, 112, 9530-9537. http://pubs.acs.org/doi/abs/10.1021/jp800760q

6. P. Qin, H. J. Zhu, T. Edvinsson, G. Boschloo, A. Hagfeldt, L. C. Sun, J. Am. Chem. Soc. 2008, 130, 8570-8571. http://pubs.acs.org/doi/abs/10.1021/ja8001474

7. P. Qin, M. Linder, T. Brinck, G. Boschloo, A. Hagfeldt, L. Sun, Adv. Mater. 2009, 21, 2993-2996.

8. S. X. Tan, J. Zhai, H. J. Fang, T. G. Jiu, J. Ge, Y. L. Li, L. Jiang, D. B. Zhu. J. Eur. Chem. 2005, 11, 6272-6276.

9. K. Tanaka, K. Takimiya, T. Otsubo, K. Kawabuchi, S. Kajihara, Y. Harima, Chem. Lett. 2006, 35, 592-593. http://www.journal.csj.jp/cl-article/cl-35-6-592

10. B. Zhao, W. O. Lu, Z. H. Zhou, Y. Wu, J. Mater. Chem. 2000 , 10, 1513-1517.

11. S. D. Bella, I. Fragala, I. Ledoux, M. A. D. Garcia, T. J. Marks, J. Am. Chem. Soc. 1997, 119, 9550-9557.

12. J. L. Bredas, C. Adant, P. Tackx, A. B. Persoons, M. Pierce, Chem. Rev. 1994, 94, 243-278.

13. B. J. Coe, Acc. Chem. Res. 2006, 39, 383-393. http://pubs.acs.org/doi/abs/10.1021/ar050225k

14. R. M. F. Batista, S. P. G. Costa, C. Lodeiro, M. Belsley, M. 
M. M. Raposo, Tetrahedron 2008, 64, 9230-9238. http://www.sciencedirect.com/science/article/pii/S004040 200801329X

15. M. M. M. Raposo, A. M. C. Fonseca, G. Kirsch, Tetrahedron 2004, 60, 4071-4078.

16. R. M. F. Batista, S. P. G. Costa, M. Belsley, M. M. M. Raposo, Dyes Pigments 2009, 80, 329-336.

http://www.sciencedirect.com/science/article/pii/ S0143720808001253

17. C. Herbivo, A. Comel, G. Kirsch, M. M. M. Raposo, Tetrahedron 2009, 65, 2079-2086.

18. M. M. M. Raposo, G. Kirsch, Tetrahedron 2003, 59, 48914899.

19. B. Delley, J. Chem. Phys. 1990, 92, 508-517.

20. H. Orita, N. Itoh, Y. Inada, Chem. Phys. Lett. 2004, 384, 271-276.

21. B. Delley, Int. J. Quant. Chem. 1998, 69, 423-433.

22. J. P. Perdew, K. Barke, M. Ernzerhof, Phys. Rev. Lett. 1996, 77, 3865-3868.
23. S. Ito, P. Chen, P. Somte, M. K. Nazeeruddin, P. Liska, P. Pechy, M. Grätzel, Prog. Photovolt. Res. Appl. 2007, 15, 603-612.

24. M. Grätzel, Nature 2001,414, 338-344.

25. A. M. Asiri, S. A. Khan, Mater. Lett. 2011, 65, 1749-1752. http://www.sciencedirect.com/science/article/pii/ S0167577X11003016

26. H. Zhou, L. Wu, Y. Gao, T. Ma, J. Photoch. Photobio. A. 2011, 219, 188-194. http://www.sciencedirect.com/science/article/pii/ S1010603011000700

27. M. Al-Eid, S. Lim, K. W. Park, B. Fitzpatrick, C. H. Han, K. Kwak, J. Hong, G. Cooke, Dyes Pigments 2014, 104, $197-$ 203.

28. S. Hao, J. Wu, Y. Huang, J. Lin, Sol. Energy 2006, 80, 209-214.

29. Q. Yu, S. Lu, M. Zhang, P. Wang, J. Phys. Chem. C. 2009, 113, 14559-14566.

\section{Povzetek}

Sintetizirali in proučili smo nove donor-akceptor konjugirane derivate $N$-(5-arilazotiazol-2-il)-2-aminotiofenov z namenom določiti prispevek interakcij teh spojin po intramolekularnem prenosu naboja z molekulami topila za njihovo potencialno uporabo v sončnih celicah. UV-vidni in emisijskih spektri nakazujejo, da imajo lastnosti sintetiziranih barvil pomemben vpliv na absorpcijo in emisijo. Vpliv donorskih in akceptorskih skupin na nelinearne lastnosti smo proučevali na podlagi HOMO-LUMO energijske razlike. Elektrokemijske sončne celice (dye-sensitized solar cells, DSSCs) so bile pripravljene z uporabo sintetiziranih aril tiazolil-tiofen barvil. Spodbudni rezultati z $J_{\mathrm{SC}}\left(2,46 \times 10^{-2}\right.$ in $4,07 \times 10^{-2}$ $\left.\mathrm{mA} / \mathrm{cm}^{2}\right), V_{\mathrm{OC}}(0,429 \mathrm{~V}$ in $0,426 \mathrm{~V})$ ter $\mathrm{FF}(0,66 \%)$ vrednostmi v primerjavi z ostalimi organskimi in naravnimi oplaščenji so posledica boljše interakcije med karboksilnimi ter karbonilnimi skupinami aril azo fragmenta vezanega na ogrodje tiazolila in površino $\mathrm{TiO}_{2}$ poroznega filma. 